\title{
Implementation of Social Customer Relationship Management Using Instagram and Facebook as Songket Marketing Media
}

\author{
Ali IBRAHIM ${ }^{1}$, Rizqy ZURRIYATI ${ }^{2}$, Mira Afriana UTAMI $^{3}$, Siti Larista \\ OCTARIA $^{4}$, Tri WAHYUNI ${ }^{5}$, Luh SIADNYANI $^{6}$, YUSMANIARTI $^{7}$
}

\footnotetext{
Ialiibrahim@unsri.ac.id, Informatics Engineering, Faculty of Computer Science, Universitas Sriwijaya, Indonesia

${ }^{2}$ rzurriyatii04@gmail.com, Department of Information Systems Faculty of Computer Science, Universitas Sriwijaya, Indonesia

${ }^{3}$ miraafrianautami15@gmail.com, Department of Information Systems Faculty of Computer Science, Universitas Sriwijaya, Indonesia

${ }^{4}$ sitilarista05@gmail.com,Department of Information Systems Faculty of Computer Science, Universitas Sriwijaya, Indonesia

${ }^{5}$ triwahyuni.unsri@gmail.com, Department of Information Systems Faculty of Computer Science, Universitas Sriwijaya, Indonesia

${ }^{6}$ siadnyani98@gmail.com, Department of Information Systems Faculty of Computer Science, Universitas Sriwijaya, Indonesia

${ }^{7}$ yusmaniarti@umb.ac.id, Department of Accounting, Faculty of Economics, Universitas Muhammadiyah Bengkulu, Indonesia

*Corresponding Author : aliibrahim@unsri.ac.id
}

Keywords: Social CRM, Framework of Dynamic, CRM, customer, songket, Instagram, Facebook

\begin{abstract}
Social Customer Relationship Management (SCRM) is a strategy used by a company or organization to be able to create and maintain a good relationship with its customers and reduce the possibility of its customers moving to other products. By using social media applications. Mawar Songket Palembang is a shop that sells a variety of typical songket of Palembang. Mawar Songket Palembang requires a strategy to be able to establish relationships and improve services to its customers so that their customers remain loyal to the shop. This study aims to build a Social Customer Relationship Management (SCRM) using Instagram and Facebook applications to establish relationships and improve their services to customers. The method used in this study is Framework of Dynamic CRM method which consists of three phases namely Acquisition, Retention, Expansion. The results of the study show that respondents' answers regarding the information provided through social media is $100 \%$ that it is very needed, $96 \%$ regarding photo suitability, $90 \%$ accuracy of selling prices, $84 \%$ does not experience problems in the transaction process and respondents stated that the admin service process is very good.
\end{abstract}

\section{INTRODUCTION}

The progress of information technology today and an intense competition definitely become a center of attention for companies to understand what their customers want that leads to the level of customer satisfaction.[1] Therefore, a company should have a way or ability to quickly adapt to any changes that are happening in order to remain able to compete with existing competitors. The process of business competition is certainly felt by all economic fields, including Mawar Songket Palembang. Mawar Songket Palembang has to make a strategy to get new customers, keep old 
customers and maintain customer loyalty in the future. Customer Relationship Management is a series of integrated activities to identify, acquire, and keep profitable customers. Customer Relationship Management is also one method for developing a customer-centered business strategy.[2] The main objective is to optimize company profits through customer satisfaction by way of forming customer perceptions about the organization and products or services offered through marketers, sellers, services that make customers motivated to be loyal.

At present, company management is certainly familiar with the use of a management system that is useful for the continuity of good relations with customers. One of them is by implementing the Social Customer Relationship Management (SCRM) system at the company.[3] By using Customer Relationship Management (CRM), the relationship between companies and customers could be better to get in touch. Establishing close relationships between companies (sellers) and customers is a factor and a key to success for the company.

Handicrafts are related to a hand-made thing or activities of producing goods by hand skills (handicrafts).[4] Crafts made are usually made of various materials. This craft produces ornaments or art objects and used items that can be sold. The color of songket reflects on the social status of consumer at the time, such as green, red, yellow songket are worn by widows, while the bright colors symbolize that they want to remarry. [5] The colors of red and bright gold as motifs that become an identity of songket during the early development period and they are two main colors of the Chinese tradition. From a semiotic review, this color contains two meanings. Red means brave, while yellow (gold) means wealth, glory and prosperity ".[6]

Mawar Songket is a shop that sells various types of Palembang typical songket located on Jl. Talang kerangga No.411, 30 Ilir, Ilir Barat II Sumatera Selatan-South Sumatera. Mawar Songket Palembang weaving business is a medium industry that produces woven fabrics with a variety of patterns and colors. In the activities of weaving industry of songket silungkang, it still performs consumer data marketing and processing conventionally.[7] So that there is no good and continuous relationship between Palembang fabrics weaving business actors and consumers. Nowadays, consumers have easily compared prices, quality and speed and services of a business. and errors often occur in calculating the sales reports obtained. In the current scope of information technology, social media is one of the tools as the application of Customer Relationship Management for a company in order to establish relationships and increase customer satisfaction and loyalty. Therefore, it is necessary to do innovation in improving services by utilizing an information management concept that aims to build and maintain the best relationships with consumers using Instagram and Facebook applications. This application is currently being loved by the wider community and has an important role for employers and consumers because it makes every existing process easier.

\section{LITERATURE REVIEW}

Based on a [8] journal entitled "Customer Relationship Management Application in Songket Silungkang Marketing in Sawahlunto City" revealed that: songket weaving business is a medium industry that produces songket woven fabrics with various patterns and colors. In the activities of the songket silungkang weaving industry, it still performs consumer data marketing and processing conventionally. So, there is no good and continuous relationship between the songket silungkang weaving business and the consumers. Today, consumers have easily compared the price, quality and speed and service of a business. Therefore, it is necessary to do innovation in doing business by utilizing a management concept with the aim of building the best relationship with consumers, namely building a Customer Relationship Management Application.

Meanwhile, based on the research [9] of a journal entitled "Design of Accounting Information: Transactions Based on the Leading Online Products of Songket Riau MSME as an Improvement of Malay Songket Economy in Treasures of Cultural Wisdom of Riau" revealed that: Web 2.0 system used by songket of Riau Melayu SMEs as a center and trend to promote their products and elevate the local wisdom of Malay songket. The success of the Web 2.0 System is a web-based marketing system model with simple accounting bookkeeping that can run effectively and efficiently, which is built according to each character of the Malay Riau UKM fabrics woven. The goal is that customers are well connected to the system. SME consumers share woven fabrics product knowledge and are satisfied with product services such as ease of payment, simple web 2.0 accounting. The results of the study are expressed in an integrated system that combines all elements of Riau Malay arts and culture and financial records on a website that is easily accessible on a web basis and very useful. This is not only aimed at improving the economy of craftsmen and Malay Riau SME traders, woven fabrics, but also as a means of promotion, increasing compliant books and increasing regional income for Riau province.

Furthermore, in the [10] "Mother Nilau's woven fabrics Development Strategy in an Effort to 
Increase woven fabrics Sales in Tanjung Batu Subdistrict" produced a product development strategy aimed at expanding existing markets by developing new products to balance products issued by competitors others, but this does not escape the constraints experienced. Experienced inhibitions affect business processes that are happening and the company does not make new innovations in the process of developing products produced.

Based on the research of [7] "Electronic Model of Customer Relationship Management with a Work Centered Analysis Approach and Framework of Dynamic CRM to Improve Customer "produces an actual score of $84.68 \%$ which means that the electronic CRM model can be implemented to help provide the best service to the customer. By implementing this model, it can facilitate the communication process well so that it can reduce understanding and the Framework of Dynamic CRM method is useful in the process of obtaining information obtained from the customer into a relationship commitment.

Whereas, according to [11] in his research entitled "Implementation of Electronic Customer Relationship Management (E-CRM) Software with the Framework of Dynamic CRM Method" said that each phase in the Framework Of Dynamic method CRM relates to the frequency of objects by distinguishing features or facilities of websites that can be accessed. In a business process that takes place using electronic customer software with this method raises a good relationship with the existence of two-way communication and can increase customer satisfaction.

\section{RESEARCH METHODS}

\section{Data Collection Method}

Data collection methods used to collect data in research are as follows:

Interview

To find out the problems that exist at Mawar Songket Palembang, we conducted an interview process with the owner of Mawar Songket Palembang, namely Mrs. Putri. The interview process also aims to establish a relationship with the owner of Mawar Songket Palembang to get information easier at Mawar Songket Palembang.

\section{Observation}

In this method, observations are made of the processes that occur at Mawar Songket Palembang, especially in the marketing process of existing products. This observation is useful to find out how customers think about marketing and service of Mawar Songket Palembang.

Literature study

Literature studies are conducted by collecting several journals and studying literature review needed to support this research in order to obtain data and information.

\section{Analysis Methods}

In this analysis method, we use the framework of dynamic CRM method. This Framework of Dynamic CRM explains how the series of stages in the implementation and development of the application of CRM. The stages are analyzed by three phases of the Framework Of Dynamic CRM method [15], which are:

[1] Phase of Acquisition is a phase that a company will understand better its customers by approaching customers to obtain customer data information. Then, this phase of acquisition will be implemented in acquire, which is the stage to get new customers.

[2] Phase of Retention is a process of company that is easier to convey information that will be given to customers about the company. Then, this Retention Phase will be implemented in the enhance process, which is the process of improving existing relationships between companies and customers by providing attractive promos and latest product info.

[3] Phase of Expansion is a phase that a company will foster good relations with customers by understanding customer desires and providing good services in order to create increasing customer loyalty.

\section{RESULTS AND DISCUSSION}

Based on the results of the online questionnaire that has been distributed by the researchers, there are 50 respondents who have an age range of 1845 years consisting of students, employees, and housewives, etc. 

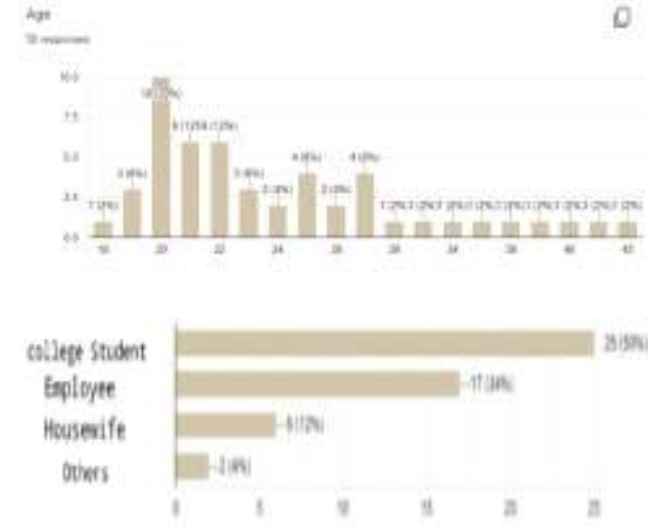

The following diagrams are the results of each question of the questionnaire:

Have you ever bought woven fabric online?

50 reoponses

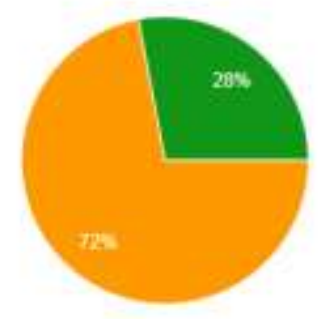

Figure 1 Online Songket Purchases

In diagram 1, relating to the purchase of songket online, the respondents stated:

- $72 \%$ said yes

- $28 \%$ said no.

Lre Ficteook and instagram medo consicerod effective in makefire woven chyen?
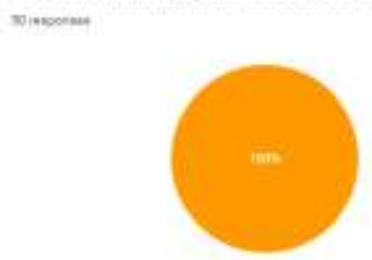

Figure 2 Songket Marketing Using

Social Media

In diagram 2, relating to the songket marketing using social media, the respondents stated $100 \%$ yes.
Does the senice that is avaliable at Palembara fose Fabric by appling social meda help in finding out information?

50 mponm

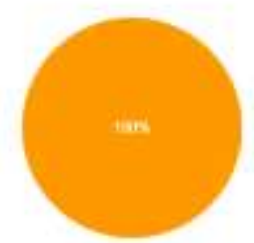

media

Figure 3 Services Using Social

In diagram 3, relating to the service using social media, the respondents stated $100 \%$ yes.

Do the products oflered by Palembang Rose Fabric through the originai photo? Sor resoneses

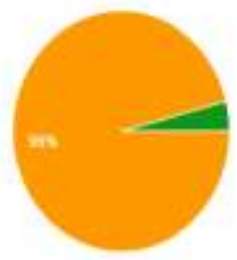

Figure 4 Photo Suitability

In diagram 4, relating to the suitability of the photo, the respondent stated:

- $96 \%$ said yes

$-4 \%$ said no.

Are the materials and prices to your liking?

50 teapanses

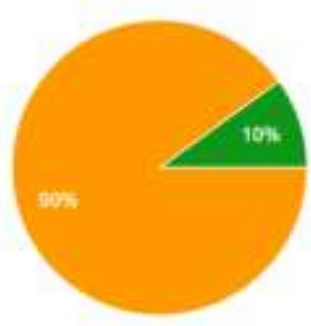

Figure 5 The Suitability Between Prices And Materials 
In diagram 5, relating to the suitability between prices and materials, the respondent stated:

- $90 \%$ said yes

$-10 \%$ said no.

Is the service on Patembarng Rose Whawing Cloth good?

stereanses

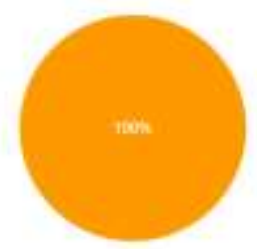

Figure 6 Mawar Songket

Palembang Service Is Good

In diagram 6, relating to Mawar Songket service is good, the respondents stated $100 \%$.

If you have ever dune a tronsaction on Plakmberys Woren fabric, ave there any ocotocies diring the enicpino process?

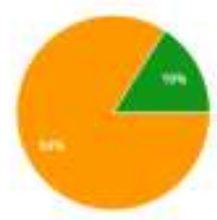

Figure 7 Inhibition During Delivery Process

In diagram 7 , relating to the inhibition during delivery process, the respondents stated:

$-16 \%$ said yes

- $84 \%$ said no.

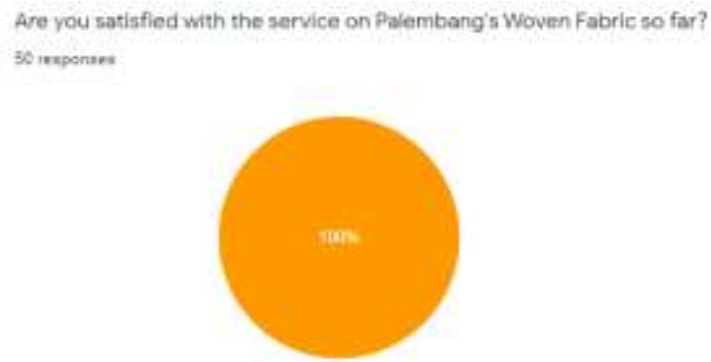

Figure 8 Stratified With The Serviced Provided

In diagram 8 , relating to being satisfied with the service provided, the respondent stated $100 \%$ yes.

The results of implementing the framework of dynamic Customer Relationship Management method

1. Acquisition Phase, Mawar Songket Palembang understands its customers better by approaching customers and obtaining customer data information. For example: on Facebook accounts and Instagram accounts of customers that follow Mawar Songket Palembang account. Each customer account will provide their personal information that can be seen on the profile. Furthermore, Mawar Songket Palembang can learn and know the behavior of each customer from each customer activity in their respective accounts, so that it can be used as a new source of strategy. Then, this acquisition phase will be implemented in acquire, which is the stage to get new customers by way of each customer account that follows Mawar Songket Palembang account. There will be a recommendation to follow Mawar Songket Palembang account which can indirectly provide suggestions for following Mawar Songket Palembang.

2. Retention Phase, Mawar Songket Palembang is easier to convey information that will be given to customers by uploading photos from songket collection to Mawar Songket Palembang social media account, so customers can see it wherever and 


\section{REFERENCES} will be implemented in enhance process. Mawar Songket Palembang keeps existing customers by providing attractive promos on the red-letter days and latest product infos.

3. Expansion Phase, Mawar Songket Palembang fosters good relationships with customers by understanding customer desires and providing good services to increase customer loyalty. For example, by question and answer service with customers that will be responded by the shop quickly and precisely.

\section{CONCLUSIONS}

Based on the results of the research we conducted, the conclusions can be drawn as follows:

1. From the results of the implementation of SCRM at Mawar Songket Palembang using the framework of dynamic CRM method, wherein the existing Instagram and Facebook accounts provide information about songket products sold as well as information about the profile of Mawar Songket Palembang.

2. Existing Instagram and Facebook accounts have connected consumers with owner of Mawar Songket Palembang. By connecting this process, the service and marketing of songket product information can be easier to publish.

3. By implementing SCRM in the service and marketing process, it can bring good relations between consumers and owner of Mawar Songket Palembang as well as it can increase customer satisfaction and loyalty.

\section{SUGGESTION}

In the process of implementing SCRM services and marketing, next authors can develop the features that can assist consumer more to increase high customer's satisfaction and loyalty.
[1] T. Alhaiou, Z. Irani, I. S. Evaluation, and M. Ali, "The Relationship Between Ecrm Implementation And E- Loyalty At Different Adoption Stages Of Transaction Cycle : A Conceptual Framework And Hypothesis," vol. 2009, pp. 1-12, 2009.

[2] M. M. Choudhury and P. Harrigan, "CRM to social CRM : the integration of new technologies into customer relationship management," no. October 2014, pp. 3741.

[3] C. Park, Y. Kim, C. Park, and Y. Kim, "information strategy A framework of dynamic CRM : linking marketing with information strategy," 2005.

[4] S. Chuang and H. Lin, "International Journal of Information Management The roles of infrastructure capability and customer orientation in enhancing customer-information quality in CRM systems : Empirical evidence from Taiwan," Int. J. Inf. Manage., vol. 33, no. 2, pp. 271-281, 2013.

[5] V. Grover, S. Ryul, and A. H. Segars, "Information systems effectiveness: The construct space and patterns of application," vol. 31, pp. 177-191, 1996.

[6] G. R. Hashemzadeh, S. Mohammad, S. Khaksar, and K. Nawaser, "Technological dimension of customer relationship management," vol. 4, no. 11, pp. 15651572, 2011.

[7] A. U. Hamdani et al., "Electronic Customer Relationship Management Model with Work Centered Analysis Approach and Framework Of Dynamic CRM To Improve Customer Service. Xyz,” pp. 361-368, 2018.

[8] A. Muhammad, E. Praja, and W. Mandala, "Application of Customer Relationship Management in Marketing (woven fabrics)," vol. 6, no. 2, pp. 52-59, 2016.

[9] R. Informasi et al., "Umkm Flagship Products (Woven Fabrics) To Enhance Riau Culture Enny Susilowati M 1), Emrinaldi Nur DP 2 ) Fakultas Ekonomi, Universitas Riau, Kampus Bina Widya Km . 1vol. 4, no. 1, pp. 57-71, 2015.

[10] Y. Yunsepa, "Development Strategies 
[13] O. Reinhold, R. Alt, and R. Alt, "How Companies are Implementing Social Customer Relationship Management : Insights From Two Case Studies,” 2013.

[11] R. Yunitarini, P. Budi, and H. Nurwarsito, "Implementation of Electronic Customer Relationship Management (E-CRM) Software with the Framework of Dynamic CRM Method," vol. 6, no. 1, pp. 83-90, 2012.

[12] R. L. Oliver, "Whence Consumer Loyalty?,” pp. 33-44, 1987.
[14] R. Shaw and A. S. Atkins, “Application Of A Customer Relationship Management System For A Large Independent Travel Agent," 2004.

[15] P. C. Verhoef, "Understanding the Effect of Efforts on Customer Retention and," vol. 67, no. October, pp. 30-45, 2003. 